\title{
PERTUMBUHAN BIBIT KELAPA SAWIT DI PRE-NURSERY DENGAN KOMPOSISI MEDIA TANAM DAN KONSENTRASI PUPUK CAIR Azolla pinnata BERBEDA
}

\author{
Filsafat Waruwu ${ }^{1}$, Bilman Wilman Simanihuruk $^{1^{*}}, \operatorname{Prasetyo}^{1}$, Hermansyah $^{1}$ \\ ${ }^{1}$ Program Studi Agroekoteknologi, Fakultas Pertanian Universitas Bengkulu, \\ * Corresponding Author : bilmanwilmansimanihuruk@yahoo.co.id
}

\begin{abstract}
[GROWTH OF OIL PALM SEEDLINGS IN PRE-NURSERY UNDER DIFFERENT MEDIA COMPOSITIONS AND CONCENTRATIONS OF Azolla pinnata LIQUID FERTILIZER ]. Vigourous seedling is prerequisite to successful production of oil palm. Aside from the genetic quality of the planting material, supply of nutrients during early growth of the seedling play an important role in determinting the overall seedling performances. This study was performed to determine the best combination of media composition and concentration of liquid fertilizer made of Azolla pinnata for oil palm seedling growth during pre-nursery. A factorial arrangement of the treatments involving growing media consisted of different composition of oil palm empty fruit bunches compost and soil (1: 1, 1:2, and 2: $1 \mathrm{v} / \mathrm{v})$ and different concentration of Azolla pinnata liquid fertilizer applications $(0,20,40$, and $60 \mathrm{~mL} / \mathrm{L})$ were arranged in a randomized complete block design with three replications. Data were collected for leaf number, stem diameter, seedling height, and leaf greenness at 30, 60, and 90 days after sowing (DAS). A significant interaction effect between the treatments was observed on leaf number at 60 and 90 DAS. A further regression analysis revealed that the highest number of leaves (4.3 at 60 DAS and 6.9 at 90 DAS) were attained on the media composition of 1:1 with liquid fertilizer application at 37.5 and $56 \mathrm{~mL} / \mathrm{L}$, respectively. Seedling height and stem diameter at 90 DAP showed quadratic responses to the increasing concentration of the liquid fertilizer applications. The maximum seedling height $(26.22 \mathrm{~cm})$ was attained at the liquid fertilizer concentrations of $36.21 \mathrm{~mL} / \mathrm{L}$. Similarly, the maximum stem diameter $(7.43 \mathrm{~mm})$ was attained at the concentration of $51.00 \mathrm{ml} / \mathrm{L}$. The leaf greeneess at $60 \mathrm{DAS}$ was increased in a linear fashion with the increasing concentration of the liquid fertilizer.
\end{abstract}

Keyword: Azolla pinnata, liquid fertilizer, oil palm, pre-nursery

\begin{abstract}
ABSTRAK
Bibit yang berpenampilan prima merupakan prasyarat bagi keberhasilan budidaya kelapa sawit. Selain karena faktor genetik, penyediaan hara pada awal pertumbuhan bibit memiliki peran penting dalm menentukan penampilan bibit secara menyeluruh. Penelitian ini dilaksanakan dengan tujuan untuk menetapkan kombinasi terbaik dari komosisi media tanam dan konsentrasi pupuk cair yang dibuat dari Azolla pinnata bagi pertumbuhan bibit kelapa sawit selama pre-nursery. Perlakuan media tanam yang tersusun dari campuran kompos tandan kosong sawit dan tanah $(1: 1,1: 2$, dan 2: $1 \mathrm{v} / \mathrm{v})$ dan aplikasi pupuk cair yang terbuat dari Azolla pinnata $(0,20,40$, dan $60 \mathrm{~mL} / \mathrm{L})$ disusun secara faktorial dengan rancangan acak kelompok lengkap dan tiga ulangan. Data dikumpulkan melalui pengamatan jumlah daun, diameter batang, tinggi bibit, dan tingkat kehijauan daun pada 30, 60, dan 90 hari setelah penyemaian (HSS). Interaksi antar perlakuan berpengaruh nyata terhadap jumlah daun 60 dan 90 HSS dan hasil analisis regresi menunjukkan bahwa jumlah daun terbanyak (4.3 pada 60 HSS dan 6.9 pada 90 HSS) dicapai pada media dengan komposisi 1:1 v/v dengan aplikasi pupuk cair masing-masing sebesar 37.5 and $56 \mathrm{~mL} / \mathrm{L}$. Tinggi bibit dan diameter bibit menunjukkan respon dengan pola kuadratik seiring dengan peningkatan konsentrasi pupuk cair. Tinggi bibit maksimum $(26.22 \mathrm{~cm})$ dicapai pada aplikasi pupuk cair dengan konsentrasi $36.21 \mathrm{~mL} / \mathrm{L}$ dan diameter batang maksimum $(7.43 \mathrm{~mm})$ dicapai pada konsentrasi $51.00 \mathrm{ml} / \mathrm{L}$. Tingkat kehijaun daun pada $60 \mathrm{HSS}$ meningkat secara linear seiring dengan peningkatan konsentrasi pupuk cair yang diaplikasikan
\end{abstract}

Kata kunci: kelapa sawit, pre nursery, pupuk cair, Azolla pinnata

JIPI. $20(1): 7-12(2018)$ 


\section{PENDAHULUAN}

Kelapa sawit (Elaeis guineensis Jacq.) adalah salah satu komoditi perkebunan yang penting di Indonesia, karena merupakan sumber perolehan devisa negara yang cukup besar. Data ini juga tercantum luas areal perkebunan kelapa sawit di Provinsi Bengkulu mencapai 308.669 ha, dengan produksi sebesar 914.103 ton sawit.

Dalam pengembangan kelapa sawit, bibit merupakan produk dari suatu proses pengadaan tanaman yang dapat berpengaruh terhadap pencapaian hasil produksi dan masa selanjutnya. Pembibitan merupakan langkah awal dari seluruh rangkaian kegiatan budidaya tanaman kelapa sawit. Bibit kelapa sawit yang baik memiliki kekuatan dan penampilan tumbuh yang optimal serta berkemampuan dalam menghadapi kondisi cekaman lingkungan saat pelaksanaan transplanting (Asmono et al., 2003). Untuk memperoleh bibit kelapa sawit yang baik, maka diperlukan perlakuan khusus terhadap media tanam dan pupuk yang digunakan selama proses pembibitan.

Kompos TKKS mengandung unsur hara utama $\mathrm{N}, \mathrm{P}, \mathrm{K}$, dan $\mathrm{Mg}$ yang dapat mendukung pertumbuhan tanaman pada pembibitan. Asra et al. (2015) menyatakan bahwa pemberian bahan organik yang berasal dari kompos TKKS dapat memudahkan penyerapan $\mathrm{N}$ oleh tanaman, yakni nitrat dan ammonium. Kedua unsur ini mempercepat pembentukan hijau daun (klorofil) untuk proses fotosintesis khususnya bibit kelapa sawit di pre-nursery. Kombinasi $50 \mathrm{~g} /$ polybag asam humat dan $75 \mathrm{~g} /$ polybag kompos TKKS memberikan peningkatan tertinggi pada tinggi tanaman, jumlah daun, diameter bonggol, dan berat kering dibandingkan kombinasi perlakuan lain (Sembiring et al., 2015). Hal ini menunjukkan bahwa kompos TKKS sangat baik untuk diaplikasikan pada bibit kelapa sawit.

Selain faktor media tanam yang digunakan, pembibitan kelapa sawit di pre-nursery juga perlu memperhatikan pupuk yang diberikan. Pupuk cair dapat lebih mudah diserap oleh tanaman sehingga pertumbuhan tanaman dapat lebih optimal. Pupuk cair dapat dibuat dari tanaman yang mengandung unsur hara tinggi, seperti penggunaan Azolla pinnata.

Azolla pinnata merupakan jenis tumbuhan paku air yang hidup di perairan. Azolla pinnata memiliki kemampuan untuk bersimbiosis dengan mikroorganisme pengikat nitrogen yakni Anabaena azollae sehingga secara tidak langsung tanaman ini memiliki kemampuan untuk mengikat $\mathrm{N}$ bebas yang ada di udara. Azolla dapat diberikan dalam bentuk segar, kering ataupun dalam bentuk kompos. Kelebihan Azolla dibanding sumber bahan organik lain yaitu selain kadar $\mathrm{N}$ tinggi (nisbah $\mathrm{C} / \mathrm{N}$ rendah) juga mengandung hara lain seperti $\mathrm{P}$, $\mathrm{K}, \mathrm{Ca}, \mathrm{Mg}, \mathrm{Fe}$, lemak, protein, gula terlarut dalam kondisi seimbang (Suyana, 2001). Kandungan N yang tinggi pada Azolla dibutuhkan tanaman dalam pertumbuhan vegetatifnya seperti daun, batang dan akar. Lebih lanjut Djojosoewito (2000) menyatakan bahwa pupuk Azolla memiliki keunggulan kandungan hara lebih tinggi dan tidak tercemar logam berat dibandingkan dengan pupuk organik lainnya.

Analisis komposisi pupuk kompos Azolla menunjukkan bahwa kandungan $\mathrm{N}$ total sebesar 2,77 $\%$, C-organik 27,72\%; dan C/N ratio 10 (Amir et al., 2012). Oleh karena itu, Azolla pinnata layak digunakan sebagai bahan pembuatan pupuk cair.

Penelitian ini bertujuan untuk mendapatkan komposisi media tanam yang tepat bagi pertumbuhan bibit kelapa sawit di pre-nursery pada setiap konsentrasi pupuk cair Azolla pinnata.

\section{METODE PENELITIAN}

Penelitian ini telah dilaksanakan di PT Bio Nusantara Teknologi, Kabupaten Bengkulu Tengah, selama tiga bulan; yaitu pada bulan April - Juli 2017 dengan ketinggian tempat $13 \mathrm{~m}$ dari atas permukaan laut (dpl).

Penelitian ini disusun secara acak menggunakan Rancangan Acak Kelompok Lengkap (RAKL) pola faktorial dengan 2 faktor. Faktor komposisi media tanam merupakan perbandingan tanah top soil dengan kompos TKKS pada polybag ukuran $1 \mathrm{~kg}$, yang terdiri atas 3 taraf yaitu : $\mathrm{M}_{1}(1: 1), \mathrm{M}_{2}(1: 2)$, dan $\mathrm{M}_{3}(2: 1)$. Faktor konsentrasi pupuk cair Azolla pinnata terdiri atas 4 taraf yaitu : $\mathrm{K}_{0}$ (kontrol : 0 $\mathrm{mL} / \mathrm{L}), \mathrm{K}_{1}(20 \mathrm{~mL} / \mathrm{L}), \mathrm{K}_{2}(40 \mathrm{~mL} / \mathrm{L})$, dan $\mathrm{K}_{3}(60$ $\mathrm{mL} / \mathrm{L})$. Dari kedua faktor tersebut diperoleh 12 kombinasi perlakuan yang diulang sebanyak 3 kali, sehingga terdiri atas 36 unit percobaan. Unit percobaan ditanam di dalam satuan polybag ukuran $1 \mathrm{~kg}$. Masingmasing unit percobaan terdiri atas 2 tanaman, sehingga secara keseluruhan diperlukan 72 benih kelapa sawit.

Pupuk cair Azolla pinnata dibuat dengan cara mencampurkan tanaman Azolla pinnata yang masih segar sebanyak $900 \mathrm{~g}$ (konsentrasi $125 \mathrm{~g}$ Azolla/L air) dengan gula merah, yang kemudian dilarutkan dalam $7 \mathrm{~L}$ air. Setelah itu dicampur dengan 10 cc EM4. Semua bahan dicampur menjadi satu kemudian dimasukkan ke dalam wadah dan ditutup rapat. Bahanbahan ini diinkubasikan selama \pm 1 minggu.

Media tanam yang digunakan adalah top soil yang dikombinasikan dengan kompos TKKS sesuai dengan rasio perlakuan. Kompos TKKS yang digunakan merupakan kompos TKKS dari PT Bio Nusantara Teknologi. 
Benih yang digunakan merupakan benih yang berasal Pusat Penelitian Kelapa Sawit (2007), varietas Tenera (persilangan antara tetua Dura dengan Psifera) yang disediakan oleh PT Bio Nusantara. Benih disemai di dalam polybag ukuran kecil $(1 \mathrm{~kg})$. Benih ditanam dengan cara membenamkannya ke dalam media tanam dengan cangkang tertanam sedalam $\pm 1 \mathrm{~cm}$ dari permukaan tanah (Badan Litbang Pertanian, 2013), kemudian ditutup kembali dengan media tanam. Papan bedeng dibuat sesuai dengan jumlah ulangan pada rancangan yang telah ditetapkan. Naungan berfungsi untuk melindungi tanaman dan permukaan media tanam dari sinar matahari dan air hujan yang berlebihan. Naungan dibuat menggunakan bambu setinggi $2 \mathrm{~m}$ bagian timur dan $1,5 \mathrm{~m}$ bagian barat, dengan atap paranet. (Hanum, 2008).

Pemeliharaan terdiri atas dua kegiatan yaitu penyiraman, dan pengendalian OPT. Penyiraman tanaman menggunakan pipa sprinkle yang telah tersedia dan dilakukan setiap hari, pagi dan sore. Pengendalian gulma dilakukan secara manual terhadap gulma-gulma yang tumbuh di sekitar tanaman dalam polybag.

Pupuk organik cair (POC) Azolla pinnata mulai diaplikasikan pada saat tanaman berumur 30 HSS, tiap minggunya sebanyak $10 \mathrm{~mL} /$ tanaman, hingga umur $60 \mathrm{HSS}$, kemudian dilanjutkan tiap minggunya sebanyak $20 \mathrm{~mL} /$ tanaman hingga umur $90 \mathrm{HSS}$. POC Azolla ini diaplikasikan dengan cara disemprotkan merata pada bagian bawah daun menggunakan handsprayer.

Pengamatan dilakukan pada saat tanaman berumur 30, 60, dan 90 HSS. Pengamatan dilakukan terhadap tinggi tanaman $(\mathrm{cm})$, diameter batang $(\mathrm{mm})$, jumlah daun (helai), luas daun $\left(\mathrm{cm}^{2}\right)$, dan persentase kehijauan daun (\%).

Tinggi tanaman diukur dari permukaan tanah sampai ujung daun terpanjang. Pengukuran tinggi tanaman dilakukan tiga kali yaitu pada umur 30, 60 dan 90 HSS. Diameter batang diukur menggunakan jangka sorong dengan satuan milimeter (mm), dengan cara mengukur diameter batang $1 \mathrm{~cm}$ dari atas permukaan tanah. Pengukuran diameter batang dilakukan pada saat bibit berumur 30, 60 dan 90 HSS. Daun yang dihitung adalah daun yang telah membuka sempurna. Penghitungan jumlah daun dilakukan dengan cara merata-ratakan jumlah daun dua bibit, pada saat tanaman berumur 30, 60, dan 90 HSS. Luas daun diukur dengan cara mengukur panjang dan lebar daun menggunakan penggaris kemudian dikalikan dengan konstanta 0,75 . Pengukuran luas daun ini dilakukan dengan cara merata-ratakan luas daun dua bibit, pada saat bibit berumur 30, 60, dan 90 HSS. Kehijauan daun diukur menggunakan alat pengukur persentase kehijauan daun (SPAD meter) dengan cara merata- ratakan 3 nilai rata-rata kehijauan dari 3 bagian daun yang telah membuka sempurna. Pengukuran persentase kehijauan daun dilakukan dengan cara merata-ratakan persentase kehijauan daun dua bibit, pada saat bibit berumur 30, 60, dan 90 HSS.

Data pengamatan dianalisis dengan uji $\mathrm{F}$ pada taraf $5 \%$. Apabila menunjukkan pengaruh yang nyata, maka digunakan metode Polynomial Orthogonal (Yitnosumarto, 1991).

\section{HASIL DAN PEMBAHASAN}

Hasil analisis varians yang ditujukan untuk melihat pengaruh perlakuan terhadap peubah yang diamati menunjukkan bahwa terdapat interaksi yang nyata $(\mathrm{P} \leq 0,05)$ antara komposisi media tanam dan konsentrasi POC Azolla pinnata pada variabel jumlah daun bibit kelapa sawit yang berumur 60 dan 90 HSS. Pengaruh mandiri komposisi media tanam tidak nyata $(\mathrm{P}>0,05)$ pada semua peubah yang diamati. Sedangkan pengaruh mandiri konsentrasi POC nyata pengaruhnya pada peubah tinggi tanaman 90 HSS, diameter batang 90 HSS dan kehijauan daun 60 HSS.

Konsentrasi POC Azolla pada komposisi media tanam 1:1 $\left(\mathrm{M}_{1}\right)$ membentuk pola respon kuadratik terhadap jumlah daun bibit kelapa sawit dengan persamaan $\hat{\mathrm{Y}}\left(\mathrm{M}_{1}\right)=2,85+0,075 \mathrm{x}-0,001 \mathrm{x}^{2}$ dan nilai koefisien determinasi $\left(\mathrm{R}^{2}\right)=0,51$ (Gambar 1). Berdasar persamaan tersebut, diperoleh konsentrasi optimum pupuk cair Azolla 37,5 ml/L dengan ratarata jumlah daun 4,25 helai. Pemberian pupuk cair Azolla pada komposisi media tanam $1: 2\left(\mathrm{M}_{2}\right)$ membentuk pola hubungan linear positif dengan persamaan $\hat{\mathrm{Y}}\left(\mathrm{M}_{2}\right)=3,45+0,005 \mathrm{x}$ dan nilai $\mathrm{R}^{2}=$ 0,13 . Persamaan yang diperoleh menunjukkan bahwa semakin meningkat konsentrasi pupuk cair $\mathrm{Az}$ olla hingga $60 \mathrm{ml} / \mathrm{L}$, maka semakin meningkat pula pertambahan jumlah daun bibit kelapa sawit. Rerata jumlah daun terbanyak rata-rata 3,75 helai pada konsentrasi $60 \mathrm{ml} / \mathrm{L}$. Pemberian konsentrasi pupuk cair Azolla pada komposisi media tanam $2: 1\left(\mathrm{M}_{3}\right)$ membentuk pola hubungan linear negatif dengan persamaan $\hat{\mathrm{Y}}\left(\mathrm{M}_{3}\right)=3,9-0,005 \mathrm{x}$ dan nilai $\mathrm{R}^{2}=0,085$. Semakin meningkat konsentrasi Azolla hingga 60 $\mathrm{ml} / \mathrm{L}$ maka semakin berkurang jumlah daun bibit kelapa sawit.

Dari seluruh interaksi, konsentrasi optimum pupuk cair Azolla pinnata adalah 37,5 ml/L pada komposisi media $1: 1\left(\mathrm{M}_{1}\right)$ yang menghasilkan rata-rata jumlah daun terbanyak yaitu 4,25 helai. Pada saat bibit berumur 90 HSS, pemberian pupuk cair Azolla pada komposisi media $1: 1\left(\mathrm{M}_{1}\right)$ membentuk pola hubungan kuadratik terhadap jumlah daun bibit kelapa sawit dengan 
persamaan $\hat{\mathrm{Y}}\left(\mathrm{M}_{1}\right)=3,75-0,001 \mathrm{x}^{2}$ dengan nilai $\mathrm{R}^{2}=$ 0,449 (Gambar 2). Konsentrasi optimum pupuk cair Azolla pada perlakuan $\mathrm{M}_{1}$ adalah $56 \mathrm{~mL} / \mathrm{L}$ yang menghasilkan rata-rata jumlah daun 6,88 helai. Pemberian perlakuan konsentrasi pupuk cair Azolla pada komposisi media $1: 2\left(\mathrm{M}_{2}\right)$ membentuk pola hubungan linear negatif terhadap jumlah daun bibit kelapa sawit dengan persamaan $\hat{Y}\left(\mathrm{M}_{2}\right)=5,35-$ $0,003 x$ dan nilai $R^{2}=0,038$. Hal ini berarti bahwa semakin tinggi konsentrasi pupuk cair Azolla hingga $60 \mathrm{~mL} / \mathrm{L}$ pada perlakuan $\mathrm{M}_{2}$, maka jumlah daun bibit kelapa sawit akan semakin berkurang pada umur 90 HSS. Rata-rata jumlah daun terbanyak adalah 5,35 helai pada konsentrasi $0 \mathrm{ml} / \mathrm{L}$ Azolla.

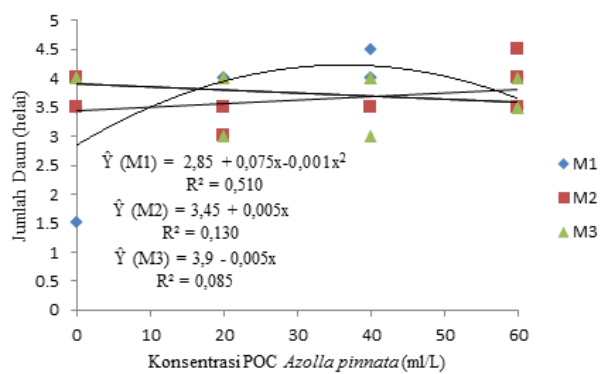

Gambar 1. Konsentrasi POC Azolla pinnata dan jumlah daun bibit kelapa sawit umur 60 HSS pada tiga komposisi media tanam

Pada saat bibit berumur 90 HSS, pemberian pupuk cair Azolla pada komposisi media $1: 1\left(\mathrm{M}_{1}\right)$ membentuk pola hubungan kuadratik terhadap jumlah daun bibit kelapa sawit dengan persamaan $\hat{\mathrm{Y}}\left(\mathrm{M}_{1}\right)=3,75-0,001 \mathrm{x}^{2}$ dengan nilai $\mathrm{R}^{2}=0,449$ (Gambar 2). Konsentrasi optimum pupuk cair Azolla pada perlakuan $\mathrm{M}_{1}$ adalah $56 \mathrm{~mL} / \mathrm{L}$ yang menghasilkan ratarata jumlah daun 6,88 helai. Pemberian perlakuan konsentrasi pupuk cair Azolla pada komposisi media $1: 2\left(\mathrm{M}_{2}\right)$ membentuk pola hubungan linear negatif terhadap jumlah daun bibit kelapa sawit dengan persamaan $\hat{\mathrm{Y}}\left(\mathrm{M}_{2}\right)=5,35-0,003 \mathrm{x}$ dan nilai $\mathrm{R}^{2}$ $=0,038$ Hal ini berarti bahwa semakin tinggi konsentrasi pupuk cair Azolla hingga $60 \mathrm{~mL} / \mathrm{L}$ pada perlakuan $\mathrm{M}_{2}$, maka jumlah daun bibit kelapa sawit akan semakin berkurang pada umur 90 HSS. Ratarata jumlah daun terbanyak adalah 5,35 helai pada konsentrasi $0 \mathrm{ml} / \mathrm{L}$ Azolla. Pemberian konsentrasi Azolla pada komposisi media $2: 1\left(\mathrm{M}_{3}\right)$ membentuk pola hubungan kuadratik terhadap jumlah daun bibit kelapa sawit dengan persamaan $\hat{\mathrm{Y}}\left(\mathrm{M}_{3}\right)=5,4-0,067 \mathrm{x}$ $+0,001 \mathrm{x}^{2}$ dan nilai $\mathrm{R}^{2}=0,291$. Konsentrasi pupuk cair Azolla yang menghasilkan jumlah daun minimum adalah $33,5 \mathrm{~mL} / \mathrm{L}$ dengan rata-rata jumlah daun 4,27 helai.

Menurut Lakitan (2000) ketersediaan unsur $\mathrm{N}$ dan $\mathrm{P}$ akan mempengaruhi daun dalam hal bentuk dan jumlah. Ada interaksi antara $\mathrm{N}$ dan $\mathrm{P}$ terhadap ketersediaan $\mathrm{N}$ dalam jaringan tanaman. Oleh karena itu wajar jika unsur $\mathrm{N}$ dan $\mathrm{P}$ menentukan jumlah daun dan tinggi tanaman (Murcitro \& Hasanudin, 2006). Penetapan dosis dan konsentrasi dalam pemupukan sangat penting dilakukan karena akan berpengaruh

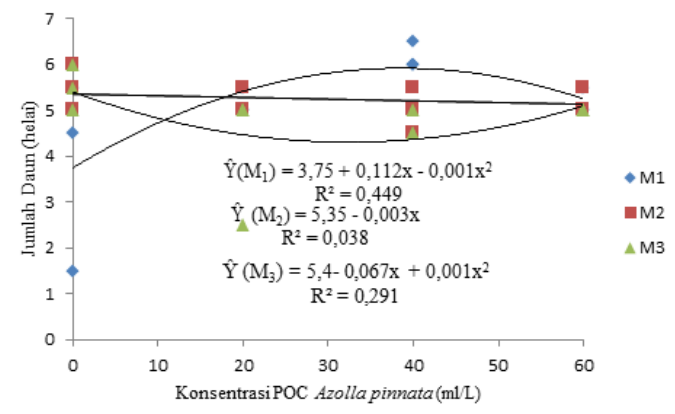

Gambar 2. Konsentrasi POC Azolla pinnata dan jumlah daun bibit kelapa sawit umur 90 HSS pada tiga komposisi media tanam

tidak baik pada pertumbuhan tanaman jika tidak sesuai kebutuhannya.

Tinggi tanaman merupakan salah satu variabel pengamatan yang menggambarkan penambahan selsel pada tanaman dari permukaan tanah ke atas. Tinggi bibit kelapa sawit diukur dari permukaan tanah hingga pucuk daun terpanjang.

Hubungan konsentrasi pupuk cair Azolla pinnata terhadap pertumbuhan tinggi bibit kelapa sawit membentuk pola kuadratik dengan persamaan $\mathrm{Y}=17,04+0,507 \mathrm{x}-0,007 \mathrm{x}^{2}$ dan nilai $\mathrm{R}^{2}=0,65$ (Gambar 3). Konsentrasi optimum pupuk cair Azolla $36,21 \mathrm{~mL} / \mathrm{L}$ yang menghasilkan tinggi bibit kelapa sawit maksimum sebesar $26,22 \mathrm{~cm}$. Penggunaan pupuk cair Azolla pada konsentrasi melebihi nilai optimum, akan menurunkan pertumbuhan tinggi bibit.

Pertambahan tinggi bibit sangat erat kaitannya dengan unsur hara makro seperti N, P dan K. Hal ini didukung dengan kandungan nutrisi pada pupuk cair

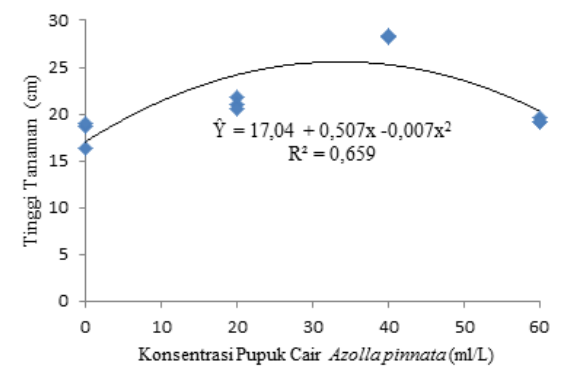

Gambar 3. Konsentrasi Pupuk Cair Azolla pinnata dan tinggi bibit kelapa sawit pada umur $90 \mathrm{HSS}$.

Azolla yang mengandung $\mathrm{N}$ total sebesar $1,645 \%$, P total $0,071 \%$, K total 2,366 \% dan Mg 0,089\% (CPS, 2014). 
Namun dalam hal ini, penentuan dosis yang tepat sangat diperlukan, karena unsur hara yang berlebihan akan mengganggu pertumbuhan dan perkembangan tanaman (Suryati \& Anom, 2014). Oleh karena itu, konsentrasi 36,21 ml/L pupuk cair Azolla pinnata merupakan konsentrasi yang tepat untuk mencukupi kebutuhan hara bibit kelapa sawit di pre-nursery.

Pengukuran diameter batang dilakukan untuk menggambarkan jumlah hara yang diserap tanaman yang dimanfaatkan untuk pertumbuhan batang. Pada umumnya semakin besar perkembangan diameter batang, maka organ-organ pada bagian atasnya seperti tinggi batang dan jumlah daun juga semakin baik pula (Suryati \& Anom, 2014). Hasil analisis varian menunjukkan bahwa konsentrasi pupuk cair Azolla pinnata berpengaruh nyata terhadap diameter batang bibit kelapa sawit pada umur 90 HSS.

Hubungan antara konsentrasi pupuk cair Azolla pinnata dan diameter batang membentuk kurva kuadratik dengan persamaan $\mathrm{Y}=4,832+102,4 \mathrm{x}-1,402 \mathrm{x}^{2}$ dengan nilai koefisien determinasi $\mathrm{R}^{2}=0,83$ (Gambar 4). Persamaan yang diperoleh menghasilkan nilai $\mathrm{x}=$ 51,00 dan nilai $\mathrm{y}=7,43$. Hasil ini menunjukkan bahwa konsentrasi optimum pupuk cair Azolla pinnata untuk meningkatkan pertumbuhan diameter batang yang tepat adalah $51,00 \mathrm{ml} / \mathrm{L}$. Penggunaan pupuk cair Azolla pada konsentrasi melebihi nilai optimum, akan menurunkan pertumbuhan diameter batang.

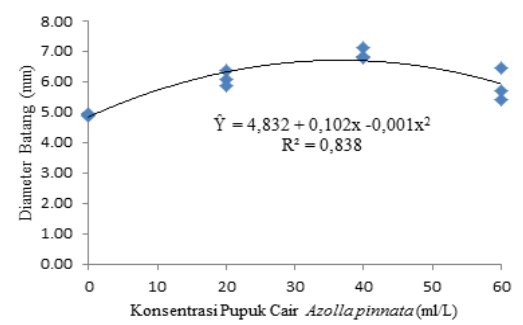

Gambar 4. Konsentrasi Pupuk Cair Azolla pinnata dan diameter batang bibit kelapa sawit pada umur 90 HSS

Pembesaran diameter batang dipengaruhi oleh ketersediaan unsur K. Penelitian Astuti (2015) menunjukkan bahwa peningkatan diameter batang tidak terlepas dari kandungan hara pada pupuk cair $A z-$ olla yang diberikan yang banyak mengandung unsur hara seperti N, P dan K. Pupuk cair Azolla mengandung $\mathrm{K}$ total 2,366 \% (CPS, 2014). Kalium berperan mempercepat pertumbuhan jaringan meristematik terutama pada batang tanaman, menguatkan batang sehingga tidak mudah rebah dan juga sangat penting dalam proses fotosintesis. Tersedianya unsur hara $\mathrm{P}$ dan $\mathrm{K}$ dapat membantu pem- bentukan karbohidrat dengan baik dan translokasi pati ke lingkarbatang sawit akan semakin lancar, sehingga akan membentuk lingkar batang semu bibit kelapa sawit dengan baik. Hal ini didukung oleh Setyamidjaja (2006) yang menyatakan bahwa $\mathrm{P}$ dan $\mathrm{K}$ dapat memperbaiki pertumbuhan vegetatif seperti lingkar batang.

Hubungan antara konsentrasi pupuk cair Azolla pinnata dan persentase kehijauan daun membentuk pola linear positif dengan persamaan $\mathrm{Y}=31,94+0,112 \mathrm{x}$ dan nilai $\mathrm{R}^{2}=0,293$ (Gambar 5). Hal ini berarti bahwa peningkatan persentase kehijauan daun seiring dengan peningkatan konsentrasi pupuk cair Azolla. Persentase kehijauan daun tertinggi rata-rata 38,66 \% diperoleh dari konsentrasi Azolla $60 \mathrm{~mL} / \mathrm{L}$ dan terendah 31,94\% pada konsentrasi $0 \mathrm{~mL} / \mathrm{L}$.

Menurut Sinaga et al. (2014), hara N sangat dibutuhkan untuk pertumbuhan tanaman karena membantu proses fotosintesis. Melalui unsur hara $\mathrm{N}$ akan terjadinya proses fotosintesis dengan adanya klorofil. Peningkatan hasil fotosintesis akan diikuti dengan bertambahnya jumlah klorofil daun, sehingga dapat meningkatkan kehijauan daun.

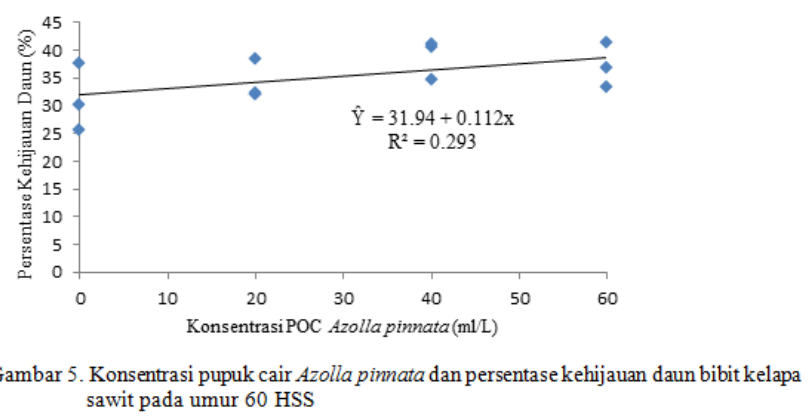

\section{KESIMPULAN}

Berdasarkan hasil penelitian, maka dapat disimpulkan bahwa komposisi media tanam dengan perbandingan TKKS dan tanah $(1: 1)$ dapat meningkatkan pertumbuhan bibit kelapa sawit di pre-nursery. Pupuk cair Azolla pinnata pada konsentrasi 36,21 - $51 \mathrm{~mL} / \mathrm{L}$ mampu meningkatkan pertumbuhan bibit kelapa sawit di pre-nursery pada umur 60 dan 90 HSS. Komposisi media tanam dan konsentrasi pupuk cair Azolla pinnata terbaik terdapat pada perbandingan media $1: 1$ dan konsentrasi pupuk cair Azolla pinnata 37,5 $56 \mathrm{~mL} / \mathrm{L}$ yang mampu meningkatkan pertumbuhan jumlah daun bibit kelapa sawit pada umur 60 dan 90 HSS. 


\section{DAFTAR PUSTAKA}

Amir, L., Sari, A. P., \& Jumadi, O. (2012). Ketersediaan Nitrogen Tanah dan Pertumbuhan Tanaman Bayam (Amaranthus tricolor L.) yang Diperlakukan dengan Pemberian Pupuk Kompos Azolla. Sainsmat, 1(2), 167-180.

Asmono, D., Purba A.R., Suprianto E., Yenni Y., \& Akiyat. (2003). Budidaya Kelapa Sawit. Pusat Penelitian Kelapa Sawit, Medan.

Asra, G., Simanungkalit, T., \& Rahmawati, N. (2014). Respons Pemberian Kompos Tandan Kosong Kelapa Sawit dan Zeolit Terhadap Pertumbuhan Bibit Kelapa Sawit diPre Nursery. AGROEKOTEKNOLOGI, 3 (1), 416-426.

Astuti, P. (2015). Uji Beberapa Konsentrasi Pupuk Cair Azolla pinnata Pada Bibit Kelapa Sawit (Elaeis guineensis Jacq.) di Pembibitan Awal. Jurnal Online Mahasiswa (JOM) Bidang Pertanian, 2 (1), 1-8.

Badan Pusat Statistik (BPS). (2015). Statistik Perkebunan Indonesia Tahun 2014 - 2016 Tanaman Kelapa Sawit. Direktorat Jenderal Perkebunan, Jakarta.

Badan Litbang Pertanian. (2013). Petunjuk Teknis Pembibitan Kelapa Sawit. http://pustaka.litbang. pertanian.go.id/agritek/psawit01.pdf. Diakses pada 07 April 2016.

Central Plantation Service (CPS). (2014). Hasil Analisis Pupuk Cair Azolla. PT. Central Alam Resources Lestari, Pekanbaru.

Djojosoewito, S. (2000). Azolla Pertanian Organik dan Multiguna. Kanisius, Yogyakarta.

Hanum, C. (2008). Teknik Budidaya Tanaman. Direktorat Pembinaan Sekolah Menengah Kejuruan. Direktorat Jenderal Manajemen Pendidikan Dasar dan Menengah, Departemen Pendidikan Nasional.
Lakitan, B. (2000). Dasar - Dasar Fisiologi Tumbuhan. Edisi Revisi. PT.Raja Grafindo, Jakarta.

Murcitro, B. G., \& Hasanudin, H. (2006). Peran pupuk $\mathrm{N}$ dan $\mathrm{P}$ terhadap serapan $\mathrm{N}$, efisiensi $\mathrm{N}$ dan hasil tanaman jahe di bawah tegakan tanaman karet. Jurnal Ilmu-Ilmu Pertanian Indonesia, 8 (1), 61-68.

Pusat Penelitian Kelapa Sawit (PPKS). (2007). Budidaya Kelapa Sawit dan Kultur Teknis Kelapa Sawit, Medan.

Sembiring, J. V., Nelvia, N., \& Yulia, A. E. (2016). Pertumbuhan Bibit Kelapa Sawit (Elaeis guineensis Jacq.) di Pembibitan Utama pada Medium Sub Soil Ultisol yang diberi Asam Humat danKompos Tandan Kosong Kelapa Sawit. Jurnal Agroekoteknologi. 6(1):25-32.

Setyamidjaja, D. (2006). Kelapa Sawit. Kanisius, Yogyakarta.

Sinaga, P., Meiriani, M., \& Hasanah, Y. H. Y. (2014). Respons Pertumbuhan dan Produksi Kailan (Brassica oleraceae L.) pada Pemberian Berbagai Dosis Pupuk Organik Cair Paitan (Tithonia diversifolia (Hemsl.) Gray). AGROEKOTEKNOLOGI, 2 (4).1584-1588.

Suyana, J. (2001). Laju Pertumbuhan dan Penambatan $\mathrm{N}_{2}$ Azolla Pada Berbagai Intensitas Penyinaran dan Tinggi Genangan. Sains Tanah: Journal of Soil Science and Agroclimatology, 1(1), 17-24.

Suryati, D., \& Anom, E. (2014). Uji Beberapa Konsentrasi Pupuk Cair Azolla (Azolla pinnata) pada Pertumbuhan bibit kelapa sawit (Elaeis guineensis Jacq.) di Pembibitan Utama. Jurnal Online Mahasiswa (JOM) Bidang Pertanian, 1 (2), 1-13.

Yitnosumarto, S. (1991). Percobaan Perancangan, Analisis, dan Interpretasinya. Gramedia Pustaka Utama, Jakarta. 